\title{
The discourses of risk of drug users in prison
}

\author{
Clua-García $\mathrm{R}^{1,2}$, Bañuls-Oncina $\mathrm{E}^{1}$, Imbernón-Casas $\mathrm{M}^{1}$, Jiménez-Vinaja $\mathrm{R}^{1}$ \\ ${ }^{1}$ Brians 1 Prison. Sant Esteve Sesrovires. Barcelona. \\ ${ }^{2}$ Faculty of Health Sciences of Manresa. University of Vic-Central University of Catalunya.
}

\begin{abstract}
Introduction and objectives: In the last twenty years, sociological changes and actions aimed at improving the health of inmates have contributed to decrease the prevalence of infectious diseases and overdoses among prison population. Currently, however, drug addictions treatment penitentiary programs are questioned for lacking of innovation and deficiencies in coverage. In order to investigate this issue we analyzed the discourses of imprisonned people regarding drug use and drug addiction programs.

Materials and methods: We applied a qualitative phenomenological method. We carried out four discussion groups with 29 encarcerated drug users and made an analysis of the discourse about different possitionings towards drug use and drug addiction treatment programs.

Results: From the combination of positions regarding drug use and drug addiction treatment programs emerged three kind of discourses respectively called: a) "reckless", characteristic of people implied in risk practices without taking preventive measures; b) "adventourous", tipical of those that take drugs both keeping the benefits of these practices and controls its negative consequences using prevention measures; c) "prudent”, of abstainers or occasionally users that minimize risks and damages.

Discussion: Encarcerated population accept drug use practices based on three risk discourses. The present study shows out that, in order to increase the effectiveness of drug policies in prison, drug treatement programs goals must be adapted to drug users particular economization of risk strategies.
\end{abstract}

Keywords: harm reduction, methadone, needle-exchange programs, program evaluation, qualitative research, HIV infections, hepatitis C, prisons.

Text received: 22/05/2018

Text accepted: 24/07/2018

\section{INTRODUCTION}

The prison population of Spain presents a prevalence of drug consumption and problems associated with intravenous use (HIV, hepatitis B and C, tuberculosis, etc.) that is higher than amongst the general public. However, in the last twenty years a general reduction has been noted in the proportion of consumers of all substances ${ }^{1,2}$ and of intravenous drug users (IDU) in prison, due to the rejection by new generations of intravenous use $\mathrm{e}^{3,4}$ and by the increase in immigrants who are less likely to be por IDUs ${ }^{4,5}$. These sociological changes along with measures taken to improve inmates' health, including disease prevention and control programmes, and harm reduction and health promotion programmes, have contributed towards reducing the prevalence of contagious dis- eases (HIV, hepatitis, etc.) and of overdoses amongst the prison population ${ }^{6}$.

However, drug consumers with serious health problems continue to be detected, many of whom are IDUs, and there is a low provision of harm reduction programmes, which is a cause for concern, to hold back re-infection of HIV and hepatitis B and C in this context ${ }^{7}$. At present, it is highly likely that the changing profile of the prison population may have had a negative influence on the administrative bodies responsible with regard to continuing to promote specific programmes for drug dependencies.

The questions that arise in view of this state of affairs are: what are the assumed risks of drug consumption, and what are the positions taken towards proposed intervention measures inside prison. No qualitative studies that have explored this issue are 
known of to date. From a socio-cultural perspective, it was considered that the practices and discourses with regard to drug consumption are determined on the basis of the experience of risk, and need to be analysed in the context within which drug consumers interact ${ }^{8}$. With this idea in mind, the study works from the notion that acceptability of different types of consumption is symbolically constructed according to the economisation of the risk of the individuals and collectives ${ }^{9,10}$.

Having detected this problem in the Brians 1 prison, this study was conducted in order to analyse the risk discourses of the prison population about drug consumption and drug dependency programmes, which are necessary elements in guiding the design of more effective drug policies.

\section{MATERIALS AND METHODS}

The study involved qualitative research carried out using Schütz's ${ }^{11}$ phenomenological method. This approach enabled the development of a theory of the participants' experiences and discourses, which assume that reality is understandable from the common meaning that they manage. This study was carried out at the Prison of Brians 1 de Sant Esteve Sesrovires (Barcelona), a mixed sentence prison with a capacity for 1,500 inmates (preventive custody centre since early 2017). Four discussion groups were run from July to November 2012, with the participation of 29 drug using inmates of 24 to 55 years of age, of whom 23 were men and 6 women (Table 1).
To organise them, users participating in drug dependency programmes were contacted and the snowball ${ }^{12}$ technique was used to access the hidden population recommended by known user discussion group participants. The groups were made up of users from different modules in the prison. They were not selected to reproduce a demographic situation, but rather to bring together a group of people who could guarantee relevant discourses relating to the objectives of the research. To this end, purposive and theoretical sampling ${ }^{13}$ was conducted, in accordance with the categories of the consumption pattern, the serological status and links to prison drug dependency programmes.

A discussion group is a technique to gain information flexibly, openly and in a non-directive manner, by activating dialogue and interaction between participants ${ }^{14-16}$. A guide with the following key issues was prepared to compile the information:

- Reasons for consumption in prison.

- Types of drugs consumed and method of use.

- Assessment of harm prevention, treatment and reduction programmes.

- Proposals to improve drug dependency interventions.

The discussion groups were run in a multipurpose room, located outside the premises of the residential modules, they were recorded on audio and textually transcribed for subsequent analysis; although analysis of the discourse commenced over the course of the sessions. To this end, encouragement techniques were used to make the participants

Table 1. Design of the discussion groups and characteristics of the participants.

\begin{tabular}{ll}
\hline $\begin{array}{l}\text { Discussion group } 1 \\
\text { (DG1) }\end{array}$ & $\begin{array}{l}\text { Made up of four men and two women of between } 37 \text { and } 47 \text { years of age. Long-standing drug users, } \\
\text { with occasional drug consumption. All of them were health agents, they were not MMP users and } \\
\text { did not use the NEP. Five were infected by HCV, without treatment, of which two were HIV+ in } \\
\text { treatment. }\end{array}$ \\
\hline $\begin{array}{l}\text { Discussion group } 2 \\
\text { (DG2) }\end{array}$ & $\begin{array}{l}\text { Made up of six men and two women of between } 31 \text { and } 46 \text { years of age. Long-standing drug } \\
\text { users, with active consumption. All of them were health agents, five were in MMP, of whom two } \\
\text { participated in NEP. Five were infected by HCV+, without treatment, of whom two were HIV+ } \\
\text { without treatment. }\end{array}$ \\
\hline $\begin{array}{l}\text { Discussion group } 3 \\
\text { (DG3) }\end{array}$ & $\begin{array}{l}\text { Made up of seven men and two women of between } 24 \text { and } 55 \text { years of age. In this group participated } \\
\text { hidden users. None of them were in MMP or participated in the NEP. Two were infected by HCV, } \\
\text { without treatment. }\end{array}$ \\
\hline $\begin{array}{l}\text { Discussion group } 4 \\
\text { (DG4) }\end{array}$ & $\begin{array}{l}\text { Made up of six men of between } 32 \text { and } 45 \text { years of age. This group included medium-long term drug } \\
\text { Five were HIV+ with treatment, one of whom was co-infected by HCV with treatment and another } \\
\text { was HCV+ without treatment. }\end{array}$ \\
\hline
\end{tabular}

Note. NEP: needle exchange programme. PMM: methadone maintenance programme. HCV: hepatitis C virus. HIV: human immunodeficiency virus. 
speak and solidify their discourses ${ }^{14,16}$. After the sessions, the final impressions necessary for the global analysis were noted down. To establish the orientation of the participants regarding the problem being studied, Conde's proposed Sociological analysis of discourse systems ${ }^{15}$ was used. The collected data was analysed and tagged to generated codes. Then, without losing sight of the global composition of the texts, the codes were compared and placed in categories, so as to produce an analytical list of the discourses related to the purpose of the study.

The study was previously evaluated by the Barcelona Centre of Legal Studies and Specialised Training (Centre d'Estudis Jurídics i Formació Especialitzada de Barcelona). Ethical considerations regarding the confidentiality and anonymity of the research participants were taken into consideration, in accordance with Organic Law 15/1999, of 13 December, on the Protection of Personal Data. All the participants of the groups signed an informed consent form concerning the objectives of the research and the use of the collected data.

\section{RESULTS}

When the orientations of the participants were explored, three discourses emerged, which are summarised below:

- "Reckless": engages in high-risk activities when consuming drugs without taking preventive measures.

- "Adventurous": consumes drugs while maintaining the reported benefits and controls the negative consequences of consumption by using preventive measures.

- "Prudent": is abstinent or occasionally consumes, minimising the risks of drug consumption as much as possible.

Such risk positions are determined by the use practices and by the intervention of the drug dependence programmes offered in prison. In each category the discourses of the drug using prison population are defined and contradicted.

\section{Use of drugs in prison}

Despite limited contact with the outside world, there is a clear and evident proliferation of the use in prison of different types of controlled and legal substances, some of which are prescribed under doctor's orders. The different positions regarding the reasons, substances and use practices in prison are considered below.

\section{Reasons for use}

Amongst persons with a "reckless" and "adventurous", discourse the reasons used to continue using drugs take different forms. The "adventurous" users mention consuming to break with the daily routine on given dates, such as individual or collective celebration. Another reason given is that of consuming drugs to cope with bad news about the confinement process or about personal and/or family issues. "Reckless" users talk about continuing to consume with some intensity due to difficulties in facing up to the severe nature of drug dependencies and/or situation in prison. "Prudent" users say that they engage in occasional low risk consumption practices or remain abstinent. The main reason is that they have become aware of the drug dependence process and have decided not to consume. Another reason they mention is that the drugs available in prison are low quality and have high prices for small quantities (Table 2).

\section{Substances consumed}

Participants state that the predominant drugs are cannabis (hashish), psychotropic medication and heroin, which are substances that depress the central nervous system, that help in disconnecting from the habitual dynamic of prison. One of the most widely used substances is hashish, used to combat minor discomforts in prison (anxiety, insomnia, etc.). Consumption of heroin and cocaine is rejected by "prudent" users, since they associate with generating problems in terms of dependency, health and finances. Consumption of heroin is more widespread than cocaine. Cocaine is occasionally consumed by "reckless" users and is rejected by "adventurous" and "prudent" users, because they do not regard it as adaptable to the prison environment (Table 2).

\section{Consumption practices}

The most common methods of use inside prison are oral (psychotropic drugs), pulmonary (hashish) and nasal (heroin). Intravenous drug use is rejected because it is associated with overdoses and infection by blood-borne diseases. "Prudent" users utilise this argument as a reason for not consuming by means of this method. This viewpoint can be seen in younger generations. On the other hand, "reckless" and "adventurous", users declare a preference for this method of use, especially the older users, although there is a distinction in terms of economisation of risk. "Adventurous" users make efforts to consume drugs intravenously using clean syringes, while "reckless" users declare that they use dirty or illegal 
Table 2. Drug use in prison.

\begin{tabular}{|c|c|}
\hline \multicolumn{2}{|c|}{ Reasons for use } \\
\hline \multirow{2}{*}{ Reckless } & $\begin{array}{l}\text { "I don't know many people in prison who have given it up. It's almost impossible, someone who } \\
\text { doesn't have any one day, has it the next" (DG1). }\end{array}$ \\
\hline & $\begin{array}{l}\text { "There've been days when I've taken so much that they had to stick a tube in me down to the } \\
\text { stomach. I've almost died three or four time. I carry on using but not so much now" (DG3). }\end{array}$ \\
\hline \multirow[b]{2}{*}{ Adventurous } & “Maybe it's your birthday and you feel like a party, it's a way of making the day go by” (DG2). \\
\hline & $\begin{array}{l}\text { "I've taken drugs when I wanted to feel better, it's all about problems. Maybe I got a call that made } \\
\text { me feel bad and you get really wrecked" (DG3). }\end{array}$ \\
\hline \multirow{2}{*}{ Prudent } & $\begin{array}{l}\text { "While you take drugs, you feel good, you have fun..., but there comes a time when you lose } \\
\text { everything and you say that's enough ..., it comes when you've touched rock bottom and you say } \\
\text { it's all over" (DG2). }\end{array}$ \\
\hline & $\begin{array}{l}\text { " } 30 \text { euros for crap and then you spend the whole week scrounging fags. And I say: for a shitty high } \\
\text { and now you're scrounging for fags?" (DG3). }\end{array}$ \\
\hline \multicolumn{2}{|r|}{ 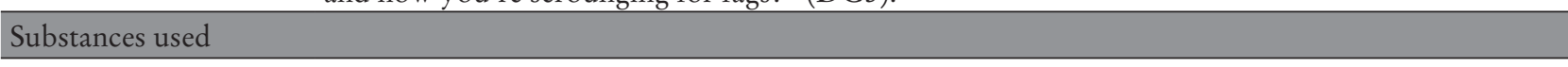 } \\
\hline \multirow{2}{*}{ Reckless } & "Now and again, I have a cocaine party" (DG2). \\
\hline & "What goes down well here is what makes you disconnect..., heroin, hashish..." (DG4). \\
\hline \multirow[t]{2}{*}{ Adventurous } & $\begin{array}{l}\text { "Taking coke in prison is crazy! I’ve done some crazy stuff but I don't take coke in prison, no } \\
\text { way!” (DG3). }\end{array}$ \\
\hline & "Taking coke with all the confinement? You take heroin, pills and hash" (DG2). \\
\hline \multirow{2}{*}{ Prudent } & $\begin{array}{l}\text { "Heroin is a problem because it destroys family financially. It's always the same old story of: I'll } \\
\text { pay you back... I'll send it to you. Never happens..." (DG2). }\end{array}$ \\
\hline & $\begin{array}{l}\text { "You've got expenses and the thing is here you're not earning, and maybe you're in a module with } \\
100 \text { euros and the prison shop is really, really expensive" (DG3). }\end{array}$ \\
\hline \multicolumn{2}{|r|}{ ( } \\
\hline \multirow[t]{2}{*}{ Reckless } & $\begin{array}{l}\text { "To really enjoy cocaine or heroin, it has be in the vein. And anyone who says otherwise is a liar! } \\
\text { How old are you? You're } 30 \text { and I'm } 44 \text {. I started to inject directly in the vein because I saw it in } \\
\text { my district, my brothers did it, may they rest in peace" (DG2). }\end{array}$ \\
\hline & $\begin{array}{l}\text { "If I don't have a contract (with the NEP) and I need to shoot up and I don't have the works } \\
\text { (syringe), I say, you have to give me one!, then I go to the bathroom ..." (DG2). }\end{array}$ \\
\hline \multirow{2}{*}{ Adventurous } & $\begin{array}{l}\text { "I've always tried to not shoot up with anyone else's works (syringe). I don't have antibodies } \\
\text { (HIV). If I want to inject, I ask for a syringe (from the NEP)" (DG1). }\end{array}$ \\
\hline & $\begin{array}{l}\text { "Me, now, I've been some time without shooting up (intravenous drug use). But if I wanted to now } \\
\text { and there was a syringe in the yard, I'd go to the medical service and ask for one" (DG4). }\end{array}$ \\
\hline \multirow{2}{*}{ Prudent } & "I smoke my joints and nothing else" (DG1). \\
\hline & "I don't like injecting in the vein" (DG3). \\
\hline
\end{tabular}

Note. DG: discussion groups. NEP: needle exchange programme. HIV: human immunodeficiency virus.

syringes (Table 2). Such practices are freely taken by consumers, but a global analysis is required, taking into consideration the needle exchange programme (NEP), which is discussed in the section below.

\section{Drug dependency intervention}

There are three teams of professionals at Brians 1 prison who carry out activities to deal with drug dependencies: the medical services, the monitoring and treatment team (MTT) and the care and monitoring centre (CMC). A number of Non-Governmental
Organisations (NGO) also participate in caring for HIV positive persons and women with related programmes. However, the participants regard the MTT and the CMC as the bodies directly responsible for drug dependencies. The discourses about the different approaches are analysed below.

\section{Drug dependency care and monitoring centre}

The CMC is a professional multidisciplinary team responsible for offering programmes and treatments for drug dependencies using a harm reduction 
approach and public health. The team respects the user's wishes in any measures it takes and sets out to provide coverage for their basic social and healthcare needs, without necessarily aiming for abstinence as the main objective. The discourses about the methadone maintenance (MMP) and the needle exchange programmes (NEP), two of the most discussed intervention measures, are analysed below.

\section{Methadone maintenance programmes}

The MMP is used to reduce or eliminate the consumption of heroin and the problems associated with use of this substance. However, the discourses offer other functions to this drug. The "reckless" user rejects the use of methadone and prefers to use heroin. The most common reasons for this are: not being controlled by the institution and not showing inferiority before other inmates, with the aim of not risking the potential stigma of being labelled a "junky" or other negative names. The MMP is used by the "adventurous" and "prudent" users, and a difference in objectives can be distinguished. The "adventurous" users declare that they combine use of methadone with that of heroin. In many cases, they ask for the dose to be increased until they obtain a certain level of intoxication, with the security of not suffering from an overdose. The "prudent" users state that the objectives of the MMP should be to: mitigate a strong addiction to heroin and reduce the dosage of methadone until abstinence is achieved. They criticise the prolonged treatments and the efforts to reach states of intoxication with this substance (Table 3).

\section{Needle exchange programme}

The main objective of the NEP is to provide hygienic materials to IDUs in order to prevent or reduce the transmission of blood-borne diseases. "Prudent" users, despite rejecting intravenous drug use, feel that the NEP is a good option for reducing risks and harm amongst IDUs. However, "reckless" users refuse to join the NEP, arguing that possession of syringes from this programme proves that there is drug use, which has a negative influence on progress in prison and means problems with prison guards. They therefore prefer to use illegal syringes or ask users of the NEP to lend them their needles. For their part, the "adventurous" users defend the aims of the programme and argue against the opinions of the "reckless" participants.

However, they make a number of recommendations to improve how the programme functions: a) ensure user confidentiality; b) make access to the programme more flexible to enable users to obtain syringes more quickly; c) improve the materials of the NEP kit: withdraw the retractable syringes and replace them with others that are better adapted to IDUs practices, and dispense more than one kit (Table 3).

\section{Monitoring and treatment teams}

The MTTs offer drug dependency programmes using a cognitive-behavioural theoretical model. Drug use is therefore correlated with criminal conduct and programmes are proposed to adopt desirable behaviours that are socially accepted and adaptable. In particular, the MTT proposes drug-free programmes for developing behaviours that enable the subject to cope with risk situations and adopt abstinence from drug use.

"Reckless" users adopt a discourse that goes against the programmes offered by the MTT, and maintain active drug use. They explain that the goal of such programmes is difficult to achieve and they prefer to make an instrumental use of them to obtain prison benefits (permits, programmed scheduled outings, etc.). They accuse the MTT programs of being a form of social control to justify the rehabilitation activities of the prison and a device to manage release from prison. On the other hand, "prudent" users declare that the programmes of the MTT encourage processes of reintegration and rehabilitation, and they highlight free choice as a central feature of the treatment, without this necessarily being a binding factor in obtaining prison benefits. The "adventurous" users combine the two previous discourses. On the one hand, they consider that the MTT programmes can be effective, but they criticise the fact that their quasi obligatory nature makes therapeutic work for drug dependency a difficult process. This group complains about staff shortages, and demands that the drug treatments should be personalised, regardless of whatever they are taken as a requirement for receiving prison benefits. That is why many discuss the pros and cons of the MTT and CMC and mention drug treatments outside prisons as effective examples of intervention in drug dependencies (Table 4).

\section{DISCUSSION}

From a global perspective, it was important to establish the discourses about drug use and drug dependency programmes in prison. The discourse orientations were identified that have enabled a better understanding of the motivations and expectations of drug users in this context.

In general terms, what is detected in the mental construct of the participants is knowledge of con- 
Table 3. Harm reduction programmes.

Methadone maintenance programme
"I can't be bothered to queue for methadone and everyone taking the piss out of me..., I know
what I have to do" (DG4).
"It's chemistry, chemistry and chemistry every day!... I go in the morning and ask for the methadone
and the psychiatric pills and I tell them I feel bad and they give it to me, they give the lot! When a
prison gives you everything it's because it's in their interests for you to be like that" (DG4).
"I like the effects of heroin, I don't like what methadone does. When I feel bad I ask for
methadone, and when I feel good I stop taking it. I like heroin, and when I don't have any and I get
aggressive, I ask for some and they give it to me" (DG2).
"Well I like the "blast" more than heroin. I think it's OK. I'm better than when I take heroin, aren't
I? It's what I'm telling you, I'm better this way than with heroin..." (DG2).
"Methadone is OK but only at a certain time. I don't think it's something you should put up with
for years and years. Once when you're in prison, stabilise, get over the withdrawal symptoms and
whatever, but you have to give it up bit by bit" (DG2).
"It's for when you feel strong, sure, because when you're hooked your mind is weak, you don't
have the same strength. So then, when you feel strong, you drop the dosage with the methadone
doctor, and you give it up and live your life!" (DG4).

Note. DG: discussion groups. NEP: needle exchange programme. HIV: human immunodeficiency virus.

sumption practices akin to surveys on health and use of drugs amongst inmates in Spanish prisons ${ }^{1,2}$ : consumption of hashish, psychiatric drugs and heroin predominates, and intravenous drug use is less and less common. The participants hold a similar viewpoint when declaring that the use of substances that depress the central nervous system takes place in order to help in better adapting to the prison environment ${ }^{17}$.

In the analysis of the discourse orientations, the "adventurous" position was most common. At the same time, certain tendencies are detected, depending on the use practices and involvement in drug dependency programmes. In the group for discussion 1 , made up of health agents, consumers in phases of abstinence predominated, which is a situation that marks out a trend towards a "prudent" orientation. In group 3, made up of concealed users, this trend was also detected. These are occasional consumers, with low risk practices (they are not injecting drug users) and with a lower presence of blood-borne diseases. This fact conveys the assumption that maintaining low risk practices is not the result of chance events, but rather a capacity for action of such consumers, as shown in other studies ${ }^{18,19}$. Both discussion group 1 and 3 showed an enthusiastic attitude that marked better psycho-social conditions in prison conduct, as indicated by Rodríguez-Martínez et al. in a study carried out in a prison in Andalusia ${ }^{20}$. In discussion groups 2 and 4, although "adventurous" users were present, a more "reckless" orientation was detected. 
These refer to using harm reduction programmes (MMP and NEP), but continue with high risk practices and distancing to always use health promotion programmes, as shown by Folch et al. in a study of the profile of injectors in Catalonia ${ }^{21}$.

A distinguishing feature in adopting positions of risk by participants can be seen in the approach to different options for harm reduction and drug dependency treatment. The ideas of the participants consisted of guidelines to implement and/or revise the preventive and therapeutic options in prison.

As regard the MMPs, the "reckless" users mention consuming heroin and not adhering to this programme so as to avoid institutional control and stigmatisation by other inmates, as shown in other studies ${ }^{22,23}$. For their part, the "adventurous" and "prudent" users take the MMP as a good option: the first group, as a way of maintaining heroin consumption; and the second one, as a therapeutic option geared to achieving detoxification. In view of the wide range of meanings given to this programme, it is considered worthwhile adapting the MMPs so that they respond to the perspectives and needs of the users themselves ${ }^{24,25}$. One alternative to methadone is to give wider diffusion to treatments with buprenorphine/naloxone, which is a safe drug, with fes medical interactions and less stigmatising, as proposed in other studies ${ }^{26,27}$. In the case of the "prudent" users, it may be considered that the posture regarding MMP detoxification could be related to family pressures or the difficulties associated with going to drug dependency centres in the community, which involves a risk of overdose in the event of a relapse, and they comment on the need to attract and retain patients in an MMP, as indicated in other studies ${ }^{22,28,29}$.

As regards the NEP, the "prudent" users, despite rejecting intravenous drug use, consider this option to be a good one to prevent infection with blood-borne diseases. The "reckless users" reject the programme in order to avoid institutional control, although they use ruses to get syringes from other users, which involves the risk of transmission of diseases, as noted in the study by Treloar et al., carried out in Australian prisons $^{30}$. For their part, the "adventurous" users recognise the benefits of the NEP, but demand a number of reforms to increase the programme's effectiveness, as demonstrated in several studies: improving access and the criteria for dispensation to increase coverage ${ }^{7,31}$; increasing the number of syringes in the dispensation ${ }^{32}$; and withdrawing retractable syringes and replacing them with others that are more adaptable to user practices ${ }^{33,34}$.

As regards the MTT drug dependency programmes, a low adherence amongst inmates is detected, as shown in a number of studies ${ }^{20,35}$. The "reckless" users allege that these programmes are a form of control, and say that the exploit them to obtain prison benefits, as shown in the study by For-

Table 4. Treatment and monitoring team programmes.

Treatment and monitoring teams
"I think the programmes offered in prison are worthless, it's to justify the prison officers' salaries"
(DG2).
"If we do drug addiction treatment it's because you want to go on the street, because I don't know
anyone that's gone to ask for one: excuse me, I want to give up and do a drug addiction programme. They
do it because the prison demands it, if not, no one here would go" (DG4).
"A programme, in my opinion, I wouldn't call it a programme, I'd call it a place where you can go when
you need it... Not somewhere to follow a programme, but a place you need from when you've decided to
give up drugs" (DG4).
"I've been in preventive custody for four years and I've looked for alternatives... and they told me that I
was in custody and so I couldn't do any programme or talk to the psychologist or do anything at all until
I was sentenced. So I got moving and they told me that the CMC could help me, so that's what I did" (DG1).
"There are tools in the street, you've got the CMC... you've got more alternatives. In the street, if you
Adventurous
want to do things, you do them, both the good and bad stuff... you can go to a psychologist...” (DG1).
"It's a great idea! There are people who want to move on up, leave the old times behind, grow up... But
you find out that most people do the programmes out of fucking obligation and then they don't let them
leave" (DG1).
"I think the programmes are fucking great because they make you see that the addiction is the tip of the
iceberg... They explained that to me in therapy, I really identified with it. I want to learn from this... I
really do" (DG3).

Note. CMC: care and monitoring centre. DG: discussion groups. 
nons, carried out at the Modelo prison in Barcelona ${ }^{17}$. The "adventurous" users who discuss the pros and cons of the MTT and CMC programmes say that they find benefits in them, but point out the contradictions between the desire to continue with the treatment and the mandatory participation in such programmes as a prerequisite to obtaining prison benefits ${ }^{17}$. Demands are made for greater coordination between the different prison drug dependency programmes and that programmes of the MTT should be carried out under their consent and be adapted to their needs for greater effectiveness ${ }^{36}$, and that more resources and staff should be available ${ }^{17,20}$. For their part, the "prudent" users who are participants in situations of abstinence say that they follow the instructions of these programmes and obtain good psycho-social support, as shown in the study by Rodríguez-Martínez et al., carried out in a prison in Andalusia ${ }^{20}$.

\section{Limitations}

The study has shown some limitations relating to selecting participants and the type of prison studied. No participants with language barriers or patients with severe mental disorders were included in the discussion groups. The latter of the two are held in psychiatric hospital prison unit, which could not be included in the study due to difficulties with bureaucratic and ethical processes. It is proposed to conduct future studies on drug use in such groups in order to analyse their specific characteristics. Despite this bias, this study has clarified elements required for guidance in and the design of new strategies in drug dependency in prisons. Finally, at the time of the research work, the prison of Brians 1 was a prison for sentenced inmates and did not include inmates held in preventive custody. At present, it is considered that the dynamics of use for this population are different from the groups studied here, and so it is necessary to consider in greater depth the use practices and social and healthcare needs of this group.

\section{CONCLUSION}

By way of conclusion, it is considered that the detection of different positions of risk between drug users in prison makes it necessary to revise the drug policies in order to design more effective social and healthcare programmes, adapted to economising risks for the different discourses of this collective.

\section{ACKNOWLEDGEMENTS}

This study was financed with assistance (D/480000100/2150) from the budget of the Centre d'Estudis Jurídics $i$ Formació Especialitzada of the Justice Department of the Regional Government of Catalonia in 2012.

\section{CORRESPONDENCE}

Rafael Clua-García

Centro penitenciario Brians 1

Sant Esteve Sesrovires. Barcelona

E-Mail: rclua@umanresa.cat

\section{REFERENCES}

1. Plan Nacional sobre Drogas. Encuesta sobre salud y consumo de drogas en internados en instituciones penitenciarias (ESDIP). Madrid: Ministerio de Sanidad, Servicios Sociales e Igualdad; 2016. Disponible en: http://servicios.mpr.es/VisorPublicaciones/visordocumentosicopo.aspx? $\mathrm{NIPO}=$ 680170956\&SUBNIPO=0001

2. Plan Nacional sobre Drogas. Encuesta sobre salud y consumo de drogas a los internados en instituciones penitenciarias ESDIP 2011. Madrid: Ministerio de Sanidad, Servicios Sociales e Igualdad; 2011. Disponible en: http://www.pnsd.mscbs. gob.es/en/profesionales/sistemasInformacion/ sistemaInformacion/pdf/ESDIP_2011.pdf

3. Martínez Oró DP, Pallarés J. Riesgos, daños y placeres. En: Martínez Oró DP, Pallarés J, editores. De riesgos y placeres: manual para entender las drogas. Lleida: Milenio; 2013. p. 23-36. Disponible en: https://observatoriodrogas.files. wordpress.com/2014/07/de-riesgos-y-placeresmanual-para-enteder-las-drogas.pdf

4. Marco A, Saiz de la Hoya P, García-Guerrero J, Grupo PREVALHEP. Multi-centre study of the prevalence of infection from HIV and associated factors in Spanish prisons. Rev Esp Sanid Penit. 2012;14:19-27.

5. Moreno R, Vera-Remartínez E, García-Guerrero J, Planelles Ramos MV. Consumo de drogas al ingreso en prisión: comparación entre población española y extranjera. Rev Esp Sanid Penit. 2008;10:41-7.

6. Hernández-Fernández T, Arroyo-Cobo JM. Results of the Spanish experience: A comprehensive approach to HIV and HCV in prisons. Rev Esp Sanid Penit. 2010;12:86-90. 
7. De la Fuente L, Bravo MJ, Jimenez-Mejias E, Sordo L, Pulido J, Barrio G. Evolution of the need and coverage of syringe exchange programs in Spanish prisons, 1992-2009: A revised estimation. Rev Esp Sanid Penit. 2012;14:86-90.

8. Sepúlveda M, Romaní O. Conceptualización y políticas de la gestión del riesgo. En: Martínez Oró DP, Pallarés J, editores. De riesgos y placeres: manual para entender las drogas. Lleida: Milenio; 2013. p. 89-102. Disponible en: https://observatoriodrogas.files.wordpress.com/2014/07/de-riesgos-y-placeres-manual-para-enteder-las-drogas. pdf

9. Douglas M. La Aceptabilidad del riesgo según las ciencias sociales. Barcelona: Paidós; 1996.

10. Spink MJP, Menegon VM. Prácticas discursivas como estrategias de gubernamentalidad: el lenguaje de los riesgos en documentos de dominio público. En: Íñiguez L, editor. Análisis del discurso. Manual para las ciencias sociales. Barcelona: UOC; 2006. p. 197-230.

11. Schütz A. La construcción significativa del mundo social. Introducción a la sociología comprensiva. Barcelona: Paidós; 1993.

12. Shaghaghi A, Bhopal RS, Sheikh A. Approaches to Recruiting "Hard-To-Reach" Populations into Research: A Review of the Literature. Health Promot Perspect. 2011;1:86-94.

13. Martínez-Salgado C. El muestreo en investigación cualitativa. Principios básicos y algunas controversias. Ciênc Saúde Colet. 2012;17:613-9.

14. Callejo J. El grupo de discusión: introducción a una práctica de investigación. Barcelona: Ariel Practicum; 2001.

15. Conde F. Análisis sociológico del sistema de discursos. Madrid, CIS; 2009.

16. Gutiérrez Brito J. Dinámica del grupo de discusión. Madrid: CIS; 2008.

17. Fornons D. Prisión y drogas: doble condena. Barcelona: deParís; 2009.

18. Mateu-Gelabert P, Friedman S, Sandoval M. Pincharse sin infectarse: Estrategias para prevenir la infección de VIH y VHC entre usuarios de drogas inyectables. Trastor Adict. 2007;9:260-8.

19. Sirikantraporn S, Mateu-Gelabert P, Friedman SR, Sandoval M, Torruella RA. Resilience Among IDUs: planning strategies to help injection drug users to protect themselves and others from HIV/HCV infections. Subst Use Misuse. 2012;47:1125-33.

20. Rodríguez-Martínez A, Ruiz-Rodríguez F, Antón-Basanta JJ, Herrera-Jáimez J, Máiquez-Pérez A, Ottaviano-Castillo A. Do drug using inmates have social support? A case study in an Andalusian prison. Rev Esp Sanid Penit. 2010;12:4-10.

21. Folch C, Casabona J, Brugal MT, Majó X, Meroño $\mathrm{M}$, Espelt A, et al. Perfil de los usuarios de drogas por vía parenteral que mantienen conductas de riesgo relacionadas con la inyección en Cataluña. Gac Sanit. 2012;26:37-44.

22. Larney S, Zador D, Sindicich N, Dolan, K. A qualitative study of reasons for seeking and ceasing opioid substitution treatment in prisons in New South Wales, Australia. Drug Alcohol Rev. 2017;36:305-10.

23. Zamani S, Farnia M, Tavakoli S, Gholizadeh M, Nazari M, Seddighi AA, et al. A qualitative inquiry into methadone maintenance treatment for opioid-dependent prisoners in Tehran, Iran. Int J Drug Policy. 2010;21:167-72.

24. Trujols J, Pérez de los Cobos J. La perspectiva de los usuarios sobre los tratamientos de mantenimiento con metadona: una revisión centrada en la satisfacción con el tratamiento. Adicciones. 2005;(17 Suppl. 2):181-204.

25. Trujols J, Garijo I, Sinol N, Del Pozo J, Portella MJ, Perez de los Cobos J. Patient satisfaction with methadone maintenance treatment: the relevance of participation in treatment and social functioning. Drug Alcohol Depend. 2012;123:41-7.

26. Marco A, López-Burgos A, García-Marcos L, Gallego C, Antón JJ, Errasti A. Is the availability of buprenorphine/naloxone therapy for opioiddependent inmates a necessity? Rev Esp Sanid Penit. 2013;15:105-13.

27. Springer SA, Qiu J, Saber-Tehrani AS, Altice FL. Retention on buprenorphine is associated with high levels of maximal viral suppression among HIV-infected opioid dependent released prisoners. PLoS One. 2012;7:e38335.

28. Degenhardt L, Larney S, Kimber J, Gisev N, Farrell M, Dobbins T, et al. The impact of opioid substitution therapy on mortality post-release from prison: retrospective data linkage study. Addiction. 2014;109:1306-17.

29. Merrall ELC, Kariminia A, Binswanger IA, Hobbs MS, Farrell M, Marsden J, et al. Metaanalysis of drug-related deaths soon after release from prison. Addiction. 2010;105:1545-54.

30. Treloar C, McCredie L, Lloyd AR. The Prison Economy of Needles and Syringes: What Opportunities Exist for Blood Borne Virus Risk Reduction When Prices Are so High? PLoS One. 2016;11:e0162399.

31. Crespo i Forte R, Codern i Bové N. Avaluació del Programa d'intercanvi de xeringues als centres 
penitenciaris de Catalunya. Bellaterra: Fundació Doctor Robert-UAB; 2010.

32. García Villanueva M, Huarte Guerra J, Fernández de la Hoz K. Siete años del programa de intercambio de jeringuillas en el Centro Penitenciario de Pamplona (España). Rev Esp Sanid Penit. 2006:8:34-40.

33. Barro J, Casillas A, Gétaz L, Rieder JP, Baroudi M, François A, Broers B, Wolff H. Retractable Syringes in a Swiss Prison Needle and Syringe Exchange Program: Experiences of Drug-using Inmates and Prison Staff Experiences. Int J Ment Health Addict. 2014;12:648-59.
34. Des Jarlais DC. "Single-use" needles and syringes for the prevention of HIV infection among injection drug users. J Acquir Immune Defic Syndr Hum Retrovirol. 1998;(18 Suppl 1):S52-6.

35. Casares-López JM, González-Menéndez A, Festinger DS, Ferández-García P, Fernández-Hermida JF, Secades R, et al. Predictors of retention in a drug-free unit/substance abuse treatment in prison. Int J Law Psychiatry. 2013;36:264-72.

36. Stevens A. The ethics and effectiveness of coerced treatment of people who use drugs. Human Rights and Drugs. 2012;2:7-15. 